\title{
The intracellular bacterium Rickettsia rickettsii exerts an inhibitory effect on the apoptosis of tick cells
}

\author{
Larissa Almeida Martins ${ }^{1,6}$, Giuseppe Palmisano' , Mauro Cortez' ${ }^{1}$, Rebeca Kawahara ${ }^{1,7}$, \\ José Mario de Freitas Balanco ${ }^{1}$, André Fujita², Beatriz Iglesias Alonso', Darci Moraes Barros-Battesti ${ }^{3}$, \\ Gloria Regina Cardoso Braz ${ }^{4}$, Lucas Tirloni ${ }^{5}$, Eliane Esteves ${ }^{1}$, Sirlei Daffre ${ }^{1}$ and Andréa Cristina Fogaça ${ }^{1 *}$
}

\begin{abstract}
Background: Rickettsia rickettsii is a tick-borne obligate intracellular bacterium that causes Rocky Mountain spotted fever, a life-threatening illness. To obtain an insight into the vector-pathogen interactions, we assessed the effects of infection with $R$. rickettsii on the proteome cells of the tick embryonic cell line BME26.

Methods: The proteome of BME26 cells was determined by label-free high-performance liquid chromatography coupled with tandem mass spectrometry analysis. Also evaluated were the effects of infection on the activity of caspase-3, assessed by the hydrolysis of a synthetic fluorogenic substrate in enzymatic assays, and on the exposition of phosphatidyserine, evaluated by live-cell fluorescence microscopy after labeling with annexin-V. Finally, the effects of activation or inhibition of caspase-3 activity on the growth of R. rickettsii in BME26 cells was determined.

Results: Tick proteins of different functional classes were modulated in a time-dependent manner by $R$. rickettsii infection. Regarding proteins involved in apoptosis, certain negative regulators were downregulated at the initial phase of the infection ( $6 \mathrm{~h}$ ) but upregulated in the middle of the exponential phase of the bacterial growth ( $48 \mathrm{~h}$ ). Microorganisms are known to be able to inhibit apoptosis of the host cell to ensure their survival and proliferation. We therefore evaluated the effects of infection on classic features of apoptotic cells and observed DNA fragmentation exclusively in noninfected cells. Moreover, both caspase-3 activity and phosphatidylserine exposition were lower in infected than in noninfected cells. Importantly, while the activation of caspase-3 exerted a detrimental effect on rickettsial proliferation, its inhibition increased bacterial growth.
\end{abstract}

Conclusions: Taken together, these results show that $R$. rickettsii modulates the proteome and exerts an inhibitory effect on apoptosis in tick cellsthat seems to be important to ensure cell colonization.

Keywords: Apoptosis, Proteome, Rickettsiae, Tick

\section{Background}

Ticks are hematophagous arthropods that parasitize almost all classes of vertebrates throughout the world, resulting in the transmission of a vast list of pathogens

*Correspondence: deafog@usp.br

1 Department of Parasitology, Institute of Biomedical Sciences, University of São Paulo, São Paulo, SP, Brazil

Full list of author information is available at the end of the article that threaten both human and animal health [1-3]. Among tick-borne diseases, Rocky Mountain spotted fever, which is caused by the obligate intracellular bacterium Rickettsia rickettsii, is one of the most severe [4-6].

The development of in vitro cell culture systems, particularly of continuous cell lines derived from tick embryos, has contributed significantly to the study of the interactions between ticks and tick-borne pathogens [7]. Of these tick cell lines, cell line BME26, which is derived 
from Rhipicephalus microplus embryonic cells, has been previously characterized by our research group [8]. Interestingly, these cells present phagocytic activity and constitutively transcribe different immunity genes, such as ferritin, heat-shock proteins, reactive oxygen species, antioxidant proteins, protease inhibitors and the antimicrobial peptides microplusin, defensin and ixodidin [8]. BME26 cells have been shown to be susceptible to Borrelia burgdorferi [9], the causative agent of Lyme disease, and to Anaplasma marginale [10], the causative agent of bovine anaplasmosis. This cell line has also previously been used as a model to analyze the transcriptional response upon exposure to $A$. marginale [11-13] and $R$. rickettsii $[12,13]$.

In the study reported here, we determined the proteome of BME26 cells in response to experimental infection with $R$. rickettsii using label-free liquid chromatography coupled with tandem mass spectrometry (LCMS/MS). Interestingly, proteins of different functional classes were modulated in a time-dependent manner. Among the proteins related to apoptosis, certain negative regulators were downregulated at the beginning of infection $(6 \mathrm{~h})$ and upregulated at a later time point $(48 \mathrm{~h})$. Previous studies have also demonstrated that $R$. rickettsii is capable of inhibiting the apoptosis in human endothelial cells [14-16]; therefore, we evaluated the effects of $R$. rickettsii infection on DNA fragmentation, tick caspase-3 activity and phosphatidylserine externalization of BME26 cells. We also assessed whether the activation and inhibition of caspase- 3 exerted an effect on bacterial proliferation. Taken together, our results show that $R$. rickettsii infection inhibits apoptosis in tick cells, which seems to be important to ensure colonization.

\section{Methods}

\section{Cell cultures and $R$. rickettsii}

The embryonic cell line of the tick Rhipicephalus microplus (Canestrini), BME26 [8], was cultured in L-15B300 medium containing $100 \mathrm{U} / \mathrm{ml}$ of penicillin and $100 \mu \mathrm{g} /$ $\mathrm{ml}$ of streptomycin and supplemented as previously described $[8,17]$. The embryonic cell line of the tick Amblyomma sculptum (Berlese), IBU/ASE-16 [18], was also cultured in L-15B300 medium supplemented with $2 \mathrm{mM}$ L-glutamine. BME26 cells were incubated at $34{ }^{\circ} \mathrm{C}$ and IBU/ASE- 16 cells at $30{ }^{\circ} \mathrm{C}$. The number of viable cells per millilter was determined using an automatic cell counter (model TC20 ${ }^{\circledR}$; BioRad, Hercules, CA, USA) after staining with $0.4 \%$ Trypan blue solution. The genomic DNA (gDNA) extracted from both cell lines was periodically evaluated by PCR using specific primers for the 16S rRNA (forward: 5'-GGG AGC AAA CAG GAT
TAG ATA CCC T-3'; reverse: $5^{\prime}$-TGC ACC ATC TGT CAC TCT GTT AAC CTC-3') to confirm the absence of Mycoplasma spp. [19].

The highly virulent Taiaçu strain of $R$. rickettsii [20] was used in the experiments. First, an inoculum of $R$. rickettsii in tick cells (BME26) was obtained. To that end, $R$. rickettsii-infected Vero cells [21] were disrupted by heat shock (three cycles of incubation at $37^{\circ} \mathrm{C}$ followed by $3 \mathrm{~s}$ in liquid $\mathrm{N}_{2}$ ) to release rickettsiae. The resulting cell lysate was transferred to BME26 cells. After $72 \mathrm{~h}$ at $34{ }^{\circ} \mathrm{C}$, the medium was removed, BME26 cells were disrupted by heat shock, as described above, and the resulting cell lysate was used to infect additional BME26 cells. After $48 \mathrm{~h}$ at $34{ }^{\circ} \mathrm{C}$, the medium was removed, the cells were harvested, suspended in supplemented L-15B300 medium containing $10 \%$ dimethyl sulfoxide (DMSO) and $5 \%$ fetal bovine serum and stored in liquid $\mathrm{N}_{2}$ before use. The same inoculum batch was used in all the experiments to guarantee equal infection. An aliquot of the infected BME26 cells was used for gDNA extraction and quantification of rickettsiae in the inoculum, as described below.

For all experiments, the culture medium was replaced by L-15B300 medium without antibiotics 3 days before infection. Cells were infected using a MOI (multiplicity of infection) of 10. As a control, cells were incubated with a lysate of noninfected BME26 or IBU/ASE-16 cells, disrupted by three cycles of incubation at $37^{\circ} \mathrm{C}$ followed by $3 \mathrm{~s}$ in liquid $\mathrm{N}_{2}$.

All experiments were conducted according to the recommendations of the Ministry of Health of Brazil.

\section{gDNA extraction}

For gDNA extraction, cells were harvested and centrifuged at $3500 \mathrm{rpm}$ for $10 \mathrm{~min}$ at $4{ }^{\circ} \mathrm{C}$. The cell pellet was resuspended in $50 \mu \mathrm{L}$ of RNAlater ${ }^{\circledR}$ (Thermo Fisher Scientific, Waltham, MA, USA) and maintained at $-20{ }^{\circ} \mathrm{C}$ until use. The gDNA was extracted using the BlackPREP Tick DNA/RNA Kit (Analytik Jena AG, Jena, Germany) according to the manufacturer's specifications. At the end of the procedure, the gDNA was quantified in a spectrophotometer (model NanoDrop-1000; Thermo Fisher Scientific) and maintained at $-20^{\circ} \mathrm{C}$.

\section{Quantification of $R$. rickettsii by quantitative PCR}

To determine the total number of rickettsiae in tick cells, the gDNA was used as a template in a quantitative PCR (qPCR) with specific primers and a hydrolysis probe [22] for the single copy gene gltA (citrate synthase) of Rickettsia spp. [23]. The gDNA extracted from noninfected cells (control) was also assayed to confirm the absence of infection. 


\section{Protein extraction and digestion}

Five biological replicates of BME26 cells infected with $R$. rickettsii for either 6 or $48 \mathrm{~h}$ were obtained. As a control, five biological replicates of BME26 cells incubated with a lysate of noninfected BME26 cells for 6 or $48 \mathrm{~h}$ were also obtained. After treatment, the cells were detached from the flasks with a cell scraper device into a sterile SPG buffer [24] containing a cocktail of protease inhibitors (P2714; Sigma-Aldrich, St. Louis, MO, USA). After centrifugation at $3500 \mathrm{rpm}$ for $10 \mathrm{~min}$, the cells were suspended in a lysis buffer $\left(100 \mathrm{mM} \mathrm{NH}_{4} \mathrm{HCO}_{3}, 8\right.$ $\mathrm{M}$ urea) containing the same cocktail of protease inhibitors described above, and then disrupted by thermal shock (three cycles of $2 \mathrm{~min}$ at $30{ }^{\circ} \mathrm{C}$ and $30 \mathrm{~s}$ in liquid $\mathrm{N}_{2}$ ). The protein concentration was determined using the bicinchoninic acid kit (BCA; Pierce ${ }^{\mathrm{TM}}$, Thermo Fisher Scientific) according to the manufacturer's instructions. From each biological replicate, $50 \mu \mathrm{g}$ of proteins was reduced with dithiothreitol (DTT, final concentration 5 $\mathrm{mM}$ ), alkylated with iodoacetamide (final concentration $10 \mathrm{mM}$ ) and digested with trypsin using a ratio of 1:50 ( $\mu \mathrm{g}$ trypsin/ $\mu \mathrm{g}$ protein) in $50 \mathrm{mM}$ ammonium bicarbonate solution at $37{ }^{\circ} \mathrm{C}$ overnight [25]. The reaction was stopped with $1 \%$ formic acid, and $10 \mu \mathrm{g}$ of the resulting peptides was desalted with ZipTip $\mathrm{C}_{18}$ (Millipore Corp., Merck Millipore, Burlington, MA, USA) and concentrated in a vacuum centrifuge.

\section{High-performance LC-MS/MS and data analysis}

The desalting peptides were suspended in $0.1 \%$ formic acid and submitted to LC-MS/MS analysis. The peptides were separated on an EASY-Column $(10 \mathrm{~cm} \times 75 \mu \mathrm{m}, 3$ $\mu \mathrm{m})$ analytical column coupled with a high-performance liquid chromatography (HPLC) Easy Nano-LC system (Thermo Fisher Scientific). For elution of the peptides, a linear gradient of 0 to $35 \%$ acetonitrile in $0.1 \%$ formic acid was used $(75 \mathrm{~min}$; flow rate $300 \mathrm{nl} / \mathrm{min}$ ). The voltage of the nanoelectrospray was $1.7 \mathrm{kV}$ and the temperature was $275{ }^{\circ} \mathrm{C}$. The mass spectrometer (model LTQ Orbitrap Velos; Thermo Fisher Scientific) was operated in data-dependent mode, automatically switching between MS and MS/MS modes. MS spectra were acquired between 400 and $2000 \mathrm{~m} / z$ on the Orbitrap analyzer, with a resolution of 60,000 . The 20 most intense ions of the MS spectra were selected and fragmented by collision-induced dissociation with $35 \%$ normalized collision energy. All biological replicates were analyzed in duplicate.

LC-MS/MS raw files were imported into the MaxQuant version 1.5.2.8 program [26], and the search tool Andromeda [27] was used to search peptides against a database. This database (Additional file 1: FASTA file) was composed of deduced amino acid sequences from transcripts obtained by RNA-seq analysis of BME26 cells [raw data were deposited to the Sequence Read Archives (SRA) of the NCBI under bioproject number PRJNA607772, and the Transcriptome Shotgun Assembly (TSA) project has been deposited at DDBJ/EMBL/GenBank under the accession GINU00000000 (the version described here is the first version, GINU01000000)] and of protein sequences from bacteria of the genus Rickettsia available in Uniprot database [28]. For protein identification, a tolerance of $10 \mathrm{ppm}$ was used for the precursor ion and $0.5 \mathrm{Da}$ for the fragment ions. Parameters included: cleavage by trypsin with a maximum of two missed cleavages, carbamidomethylation of cysteine $(57.021 \mathrm{Da})$ as a fixed modification, and oxidation of methionine (15.994 Da) as a variable modification. Peptide-spectrum matches and peptides and protein false recovery rates (FDR) were kept below $1 \%$. Only proteins identified from at least two distinct peptides were accepted. Protein quantification was performed using the LFQ (label-free quantification) feature in the quantitative proteomics software package MaxQuant. The differential proteome from infected cells in relation to control cells was determined using Perseus v.1.5.2.6 software. Only proteins with $P<0.05$ (Student's t-test) with a multiple test correction (FDR) $<5 \%$ and with a relative abundance (fold-change) $\geq 1.5$ or $\leq 0.67$ in infected cells in relation to control cells were considered to be modulated. Proteins significantly different in relative abundance between infected cells and control cells but presenting a fold-change of $<1.5$ and $>0.67$ were considered to be unmodulated. Proteins identified exclusively in infected or control samples were also considered to be modulated (up or downregulated, respectively). The MS raw files were submitted to PRIDE (https://www.ebi.ac.uk/pride/) with the submission number PXD017942. The principal component analysis was performed using the online platform MetaboAnalyst 3.0 [29].

\section{gDNA fragmentation evaluation by agarose gel electrophoresis}

The gDNA extracted from noninfected or $R$. rickettsii-infected BME26 cells at 6, 24, 48, 72, 96 and $120 \mathrm{~h}$ after the beginning of the experiment was analyzed on a $1 \%$ agarose gel electrophoresis stained with RED $^{\mathrm{TM}}$ Gel (Uniscience Corp., Miami Lakes, FL, USA). After electrophoresis with a constant voltage of $100 \mathrm{~V}$ for 60 $\mathrm{min}$, the gel was visualized under ultraviolet (UV) light in a transilluminator coupled to an imaging system (ImageQuant $^{\mathrm{TM}} 300$ model; GE Healthcare, Chicago, IL, USA). 


\section{Enzymatic assays for evaluation of caspase 3 activity}

The first step in the analysis of caspase-3 activity in BME26 cells, pre-infected or not with $R$. rickettsii for 24 , 36 or 48 h, was to induce caspase-3 activity with staurosporine (final concentration 400 nM; Sigma-Aldrich). After an additional $6 \mathrm{~h}$ of incubation, cells were detached and centrifuged at $3500 \mathrm{rpm}$ for $10 \mathrm{~min}$ at $4{ }^{\circ} \mathrm{C}$. The cell pellet was then suspended in $80 \mu \mathrm{l}$ of lysis buffer [20 $\mathrm{mM}$ piperazine- $N, N^{\prime}$-bis(2-ethanesulfonic acid) (PIPES), $100 \mathrm{mM} \mathrm{NaCl}, 2 \mathrm{mM}$ ethylenediamine tetraacetic acid (EDTA), 0.1\% 3-[(3-cholamidopropyl)dimethylammonio]1-propanesulfonate hydrate (CHAPS), $10 \%$ sucrose, $0.1 \%$ Triton X-100, $1 \mathrm{mM}$ phenylmethanesulfonyl fluoride (PMSF), $2 \mu \mathrm{M}$ pepstatin, $\mathrm{pH} 7.2$ ], followed by centrifugation at $13,000 \mathrm{rpm}$ for $5 \mathrm{~min}$ at $4{ }^{\circ} \mathrm{C}$. The supernatant (cytosol) was collected and the protein concentration determined using the BCA kit (Pierce ${ }^{\mathrm{TM}}$, Thermo Fisher Scientific), according to the manufacturer's instructions. Aliquots of $50 \mu \mathrm{g}$ of proteins from each sample were incubated at $37{ }^{\circ} \mathrm{C}$ with $50 \mu \mathrm{M}$ of the Ac-DEVD-AMC synthetic substrate (Calbiochem ${ }^{\circledR}$; Merck KGaA, Darmstadt, Germany) (FluoroNunc ${ }^{\mathrm{TM}}$ well plates; Thermo Fisher Scientific) in $50 \mathrm{mM}$ HEPES ( $N$-2-hydroxyethylpiperazine$N^{\prime}-2$ ethanesulfonic acid) buffer, $\mathrm{pH} 7.0$, containing 10 mM DTT. The release of aminomethyl coumarin (AMC) fluorescence was continuously monitored for $1 \mathrm{~h}$ at 5 -min intervals using a fluorimeter (SpectraMax ${ }^{\circledR} \mathrm{i} 13$; Molecular Devices, San Jose, CA, USA) set at wavelengths of 380 $\mathrm{nm}$ for excitation and $460 \mathrm{~nm}$ for emission. The relative activity of caspase- 3 was calculated using the ratio of the $\triangle \mathrm{UAF}$ (units of arbitrary fluorescence; $\mathrm{UAF}_{60 \text { min }}-\mathrm{UAF}_{0}$ min) of the target condition by the $\triangle \mathrm{UAF}$ of the reference condition $\left(\triangle \mathrm{UAF}_{\text {target condition }} / \Delta \mathrm{UAF}_{\text {reference condition }}\right)$. The same procedure was used to evaluate caspase-3 activity in BME26 or IBU/ASE-16 cells infected with $R$. rickettsii or challenged with heat-inactivated $R$. rickettsii. The inactivation of rickettsiae was obtained by exposure to heat at $56{ }^{\circ} \mathrm{C}$ for $1 \mathrm{~h}$. After inactivation, rickettsiae were inoculated to BME26 cells and bacterial growth was evaluated after $6,24,48$ and $72 \mathrm{~h}$ by qPCR. No bacterial growth was detected, showing that bacteria were efficiently inactivated by heat (data not shown). Forty-eight hours after exposure to rickettsiae, staurosporine (final concentration $400 \mathrm{nM}$ ) was added to the cells and caspase- 3 activity was assessed as described above. Caspase- 3 activity was also evaluated in uninfected cells as well as in cells nontreated with staurosporine, as a control. At least three biological replicates of each condition were analyzed in three technical replicates. Data were statistically analyzed by Student's t-test using GraphPad Prism (v6.0; GraphPad Software Inc., San Diego, CA, USA), and the activity of caspase-3 was considered to be significantly different at $P<0.05$.
Evaluation of apoptosis by fluorescence microscopy BME26 cells were cultured in a $35-\mathrm{mm}$ Petri dish containing a 1.5 coverglass (Nunc ${ }^{\mathrm{TM}}$ Glass Bottom Dishes; 1.2 $\times 10^{6}$ cells per dish; Thermo Fisher Scientific) and maintained at $34{ }^{\circ} \mathrm{C}$ for $24 \mathrm{~h}$. The BME26 cells were infected with $R$. rickettsii or challenged with heat-inactivated R. rickettsii; noninfected cells were used as the control. After $48 \mathrm{~h}$, staurosporine (final concentration $400 \mathrm{nM}$ ) was added to the cells and the cells incubated for an additional $6 \mathrm{~h}$, following which the cells were labeled for $15 \mathrm{~min}$ with $1 \mu \mathrm{l} / \mathrm{ml}$ of annexin- $\mathrm{V}$ conjugated to Alexa Fluor $^{\mathrm{TM}} 488$ (Invitrogen, Carlsbad, CA, USA), $0.25 \mu \mathrm{g} /$ $\mathrm{ml}$ of Hoechst 33342 and $1 \mu \mathrm{l} / \mathrm{ml}$ propidium iodide (PI). The cells were then observed under a fluorescence microscope (model DMI6000B/AF6000; Leica Microsystems $\mathrm{GmbH}$, Wetzlar, Germany) coupled to a digital camera system (model DFC365FX; Leica Microsystems GmbH). Three independent images obtained from three biological replicates were acquired and processed by the Leica Suite $\mathrm{X}$ (LAS X) software. The number of cells labeled with annexin- $V$ was determined using Image J software [30]. The number of annexin-V-labeled cells for each treatment were analyzed using a Student's t-test using GraphPad Prism software, and differences were considered to be significant when $P<0.05$.

\section{Evaluation of the effects of apoptosis on the proliferation of $R$. rickettsii in BME26}

BME26 cells were incubated with either Z-DEVD-Fmk (final concentration $10 \mu \mathrm{M}$ ), a caspase-3 inhibitor, or staurosporine (final concentration $400 \mathrm{nM}$ ). After $1 \mathrm{~h}$, the cells were infected with $R$. rickettsii. The quantification of R. rickettsii in BME26 was determined after $6,24,48,72$, 96 and 120 h by qPCR, as described above. Three biological replicates for each treatment were analyzed. Differences in bacterial growth were determined by a Student's t-test using GraphPad Prism software and considered to be significant when $P<0.05$.

\section{Results \\ Effects of rickettsial infection on the proteome of BME26 cells}

Determination of the growth curve of $R$. rickettsii in BME26 cells revealed a doubling time of $8.5 \mathrm{~h}$ (Additional file 2: Figure S1a). Progressive infection of cells was observed over time, with the vast majority of the cells infected by $96 \mathrm{~h}$ after the beginning of infection (Additional file 2: Figure S1b-e). To determine changes in the proteome of BME26 cells in response to infection, we chose two time points on the $R$. rickettsii growth curve, one in the initial phase of the infection ( $6 h)$ and the other in the middle of the exponential phase of bacterial growth $(48 \mathrm{~h})$. Proteins extracted from noninfected 
(control) and $R$. rickettsii-infected BME26 cells were reduced, alkylated and digested with trypsin, and the resulting peptides were analyzed by LC-MS/MS. The raw data thus obtained were analyzed using the MaxQuant program against a database containing deduced amino acid sequences of transcripts of BME26 cells and protein sequences of bacteria of the genus Rickettsia.

A total of 1061 proteins were identified, among which 1056 correspond to tick proteins (Additional file 3: Table S1; Additional file 4: Table S2; Additional file 5: Table S3; Additional file 6: Table S4; Additional file 7:

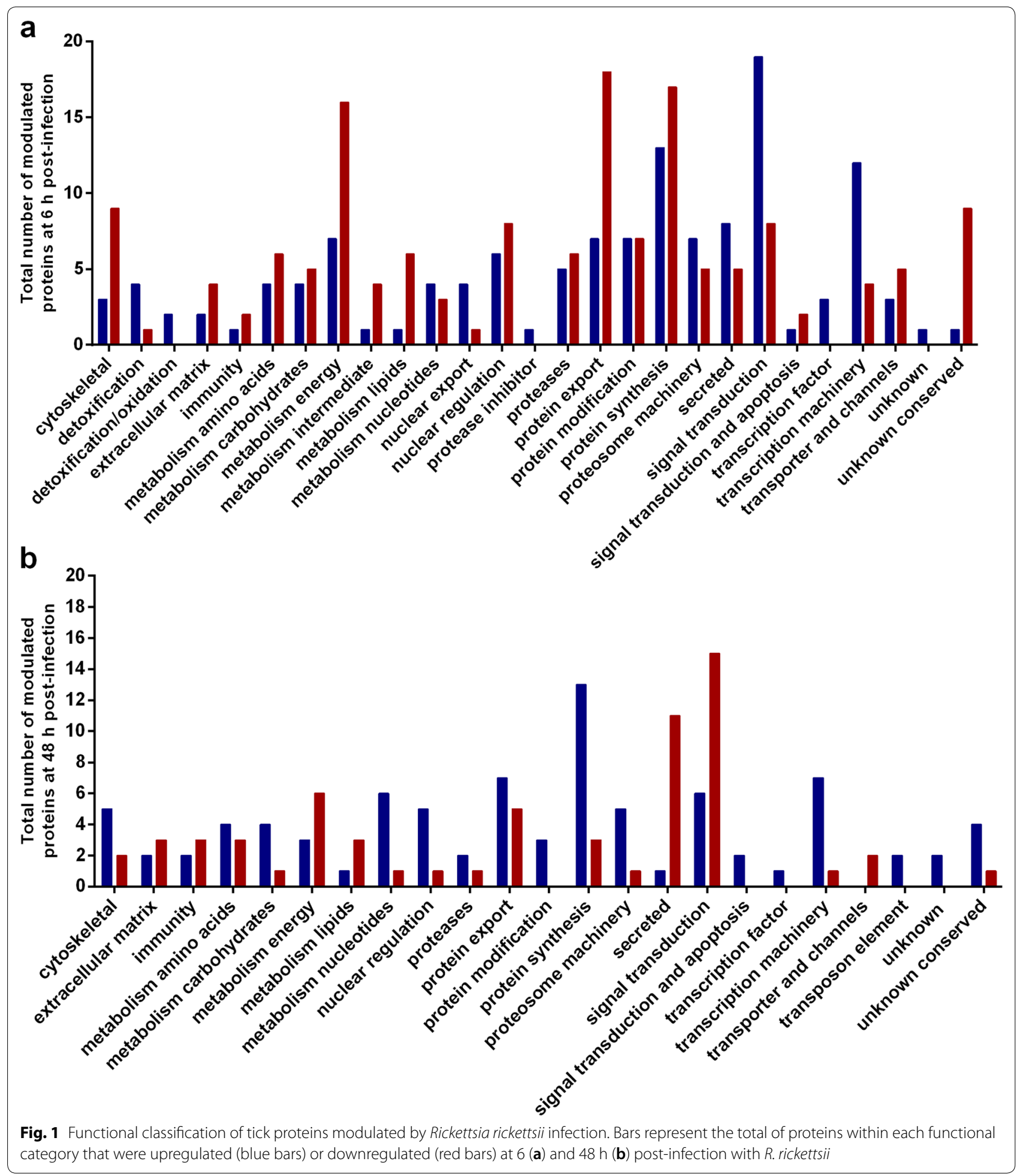


Table S5; Additional file 8: Table S6) and five to Rickettsia spp. proteins (Additional file 9: Table S7). Among the tick proteins, 789 were detected in all analyzed conditions (Additional file 10: Figure S2a). PCA of the quantitative protein features demonstrated a clear separation between the datasets of BME26 cells at 6 and $48 \mathrm{~h}$ post-infection (Additional file 10: Figure S2b). We observed separation between datasets of the control and infected cells at each of the two time points, although a slight overlap was observed at $48 \mathrm{~h}$.

At the time point of $6 \mathrm{~h}$ post-infection, 839 proteins common to both control and $R$. rickettsii-infected cells were identified (Additional file 10: Figure S2c). Among these, 47 presented a higher relative abundance $(P<0.05$ and fold-change $\geq 1.5$ ), and 92 exhibited a lower relative abundance $(P<0.05$ and fold-change $\leq 0.67)$ in infected than in control cells (Additional file 3: Table S1). A total of 59 proteins were identified exclusively in the control cells (Additional file 4: Table S2) and 84 exclusively in $R$. rickettsii-infected cells (Additional file 5: Table S3) at 6 $\mathrm{h}$ post-infection. Thus, a total of 131 proteins were considered to be upregulated (i.e. proteins with higher relative abundance in infected cells or exclusively detected in this condition) and 151 to be downregulated (i.e. proteins with relative abundance lower in infected cells or identified exclusively in control cells) in the initial phase of infection. Regarding the time point of $48 \mathrm{~h}$ postinfection, we identified a total of 853 proteins that were common to both control and infected cells (Additional file 10: Figure S2d). Among these proteins, 19 showed a higher relative abundance and 24 presented a lower relative abundance in $R$. rickettsii-infected cells compared to noninfected cells (Additional file 6: Table S4). Thirtynine proteins were identified exclusively in control cells (Additional file 7: Table S5), and 68 proteins were identified exclusively in infected cells (Additional file 8: Table S6). Thus, a total of 87 proteins were upregulated and 63 were downregulated at $48 \mathrm{~h}$ post-infection. The proteins modulated by infection were functionally classified (Fig. 1), as described by Karim and collaborators [31].

Regulatory components of the $20 \mathrm{~S}$ and $26 \mathrm{~S}$ subunits of the proteasome, which are included within the proteasome machinery category, were either upregulated (Table 1) or downregulated (Table 2) at $6 \mathrm{~h}$ post-infection. In addition, one proteasome inhibitor and one ubiquitin modifier were upregulated (Table 1), while one ATP-dependent Lon protease was downregulated at this same time point (Table 2). Despite a smaller number of proteins related to the proteasome machinery being modulated at $48 \mathrm{~h}$ post-infection, the majority were upregulated, including regulatory components of subunits $20 \mathrm{~S}$ and $26 \mathrm{~S}$ and one ubiquitin-protein ligase
(Table 1). In contrast, the Skp1/Cullin/F-box containing complex (SCF) ubiquitin ligase component was downregulated (Table 2). Regarding the cytoskeletal and actin components, the subunits Arp2 and ArpC1/p41-Arc of the Arp2/3 complex were downregulated at $6 \mathrm{~h}$ (Table 2) while the ArpC5 subunit of the same complex and actinbinding proteins, including one spectrin, were upregulated (Table 1).

Among proteins within the signal transduction and apoptosis (ST/apoptosis) category, one apoptotic chromatin condensation inducer in the nucleus was upregulated at $6 \mathrm{~h}$ (Table 1). In contrast, mucin-1 (a negative regulator of the intrinsic pathway of apoptosis signaling in response to DNA damage by the p53 mediator) and the apoptosis inhibitor 5 (this one included in the immunity category) were downregulated (Table 2). Conversely, mucin-1 was upregulated $48 \mathrm{~h}$ post-infection (Table 1 ). Other factors that negatively regulate the apoptotic process (Fanconi anemia complementation group D2 and cytokine-induced apoptosis inhibitor 1) were also upregulated at $48 \mathrm{~h}$ (Table 1).

\section{Effects of $R$. rickettsii infection on the apoptotic process of BME26 cells}

To evaluate if $R$. rickettsii exerted an effect on the apoptosis of BME26 cells, as suggested by the proteome data, the gDNA extracted from noninfected and infected cells was analyzed by electrophoresis in an agarose gel. Fragmentation of the gDNA was observed only in noninfected cells, starting at $96 \mathrm{~h}$ after the beginning of the experiment (Additional file 11: Figure S3). Subsequently, we assessed the activity of caspase- 3 induced with staurosporine (a classic activator of apoptosis [32]) in BME26 cells preinfected with $R$. rickettsii for 24,36 , and $48 \mathrm{~h}$ (Additional file 12: Figure S4). Caspase-3 activity was significantly lower in cells previously infected for $36(P<0.002)$ and 48 $(P<0.01)$ h when compared to noninfected cells.

To assess if the inhibition of caspase- 3 activity was a response of BME26 cells to components produced by live rickettsiae, cells were exposed to either viable or thermoinactivated $R$. rickettsii (Fig. 2a). Only cells infected with viable bacteria had a significantly lower caspase- 3 activity $(P<0.02)$ compared to the control. However, a slight-but not significant-reduction of caspase- 3 activity was also observed between noninfected cells and cells exposed to thermo-inactivated rickettsiae. No difference was detected among the three groups in the absence of staurosporine. For comparison purposes, we conducted a similar experiment using an embryonic tick cell line of one primary vector of $R$. rickettsii in Brazil, A. sculptum (IBU/ ASE-16) (Fig. 2b). The results showed that cells infected with live $R$. rickettsii presented a significantly lower caspase-3 activity $(P<0.0001)$ than the control. A significant 
Table 1 Selected proteins upregulated at 6 or $48 \mathrm{~h}$ post-Rickettsia rickettsii infection of BME26 cells

\begin{tabular}{|c|c|c|c|c|}
\hline \multirow{2}{*}{$\begin{array}{l}\text { Functional } \\
\text { classi of } \\
\text { proteins }\end{array}$} & \multicolumn{2}{|l|}{$6 \mathrm{~h}$ post-infection } & \multicolumn{2}{|l|}{$48 \mathrm{~h}$ post-infection } \\
\hline & ID & Annotation & $\mathrm{ID}$ & Annotation \\
\hline \multirow[t]{3}{*}{$\begin{array}{l}\text { ST/ } \\
\text { APOPTOSIS }\end{array}$} & BME26USP-64008 & $\begin{array}{l}\text { Apoptotic chromatin condensation inducer } \\
\text { in the nucleus }\end{array}$ & BME26USP-3827 & $\begin{array}{l}\text { Mucin-1—Negative regulation of intrinsic } \\
\text { apoptotic signaling pathway in response to } \\
\text { DNA damage by p53 class mediator }\end{array}$ \\
\hline & & & BME26USP-77602 & $\begin{array}{l}\text { Fanconi anemia complementation group } \\
\text { D2—negative regulation of apoptotic } \\
\text { process }\end{array}$ \\
\hline & & & BME26USP-73913 & Cytokine-induced apoptosis inhibitor 1 \\
\hline \multirow[t]{7}{*}{ PROT } & BME26USP-3792 & Small ubiquitin-related modifier 3 & BME26USP-63775 & $\begin{array}{l}\text { 26S Proteasome regulatory complex subunit } \\
\text { RPN11 }\end{array}$ \\
\hline & BME26USP-1981 & $\begin{array}{l}\text { 20S Proteasome regulatory subunit alpha } \\
\text { type PSMA5/PUP2 }\end{array}$ & BME26USP-4899 & $\begin{array}{l}\text { 20S Proteasome regulatory subunit beta type } \\
\text { PSMB1/PRE7 }\end{array}$ \\
\hline & BME26USP-61379 & $\begin{array}{l}\text { 26S Proteasome regulatory complex subu- } \\
\text { nit RPN12/PSMD8 }\end{array}$ & & \\
\hline & BME26USP-61464 & $\begin{array}{l}\text { 26S Proteasome regulatory complex } \\
\text { ATPase RPT5 }\end{array}$ & BME26USP-66020 & Ubiquitin-protein ligase \\
\hline & BME26USP-63407 & proteasome inhibitor & & \\
\hline & BME26USP-67891 & $\begin{array}{l}\text { 26S Proteasome regulatory complex subu- } \\
\text { nit RPN7/PSMD6 }\end{array}$ & BME26USP-68301 & $\begin{array}{l}20 S \text { Proteasome regulatory subunit alpha } \\
\text { type PSMA1/PRE5 }\end{array}$ \\
\hline & BME26USP-70300 & $\begin{array}{l}\text { 26S Proteasome regulatory complex subu- } \\
\text { nit RPN5/PSMD12 }\end{array}$ & & \\
\hline \multirow[t]{5}{*}{ CS } & BME26USP-SigP-75480 & Tyrosine protein kinase receptor tie-1 & BME26USP-2996 & Microtubule-associated protein partial \\
\hline & BME26USP-71952 & $\begin{array}{l}\text { Actin-related protein arp2/3 complex } \\
\text { subunit arpc5 }\end{array}$ & BME26USP-5135 & Tropomodulin and leiomodulin \\
\hline & BME26USP-71823 & Microtubule-binding protein & BME26USP-65063 & Src substrate cortactin \\
\hline & BME26USP-26177 & $\begin{array}{l}\mathrm{Ca}^{2+} \text {-Binding actin-bundling protein (spec- } \\
\text { trin) alpha chain }\end{array}$ & BME26USP-42758 & $\begin{array}{l}\text { Vinculin-Neuron projection morphogen- } \\
\text { esis/phagocytosis/actin/cytoskeleton/ } \\
\text { structural molecule/actin binding/cytoskel- } \\
\text { etal anchoring }\end{array}$ \\
\hline & & & BME26USP-69366 & Alpha tubulin \\
\hline
\end{tabular}

ST/Apoptosis, Signal transduction and apoptosis; PROT, proteasome machinery; CS, cytoskeletal functional classes, SRC

lower caspase-3 activity was also detected in cells stimulated with thermo-inactivated bacteria than in noninfected cells $(P<0.007)$. On the other hand, caspase-3 activity was significantly higher in cells stimulated with thermo-inactivated bacteria than in cells infected with viable rickettsiae $(P<0.001)$. A lower caspase-3 activity was also detected in IBU/ASE-16 cells infected with viable bacteria than in noninfected cells without staurosporine induction, although the difference was not significant.

The phosphatidylserine externalization in noninfected BME26 cells and cells exposed to viable or thermo-inactivated $R$. rickettsii was also assessed by live-cell fluorescence microscopy after labeling with annexin-V (Fig. 3a), which specifically binds to phosphatidylserine [33]. Cells were also labeled with the DNA probes Hoechst (staining live cells) and PI (staining dead/apoptotic cells). The number of annexin-V-labeled cells was significantly lower in cells infected with viable $R$. rickettsii than in noninfected cells $(P<0.0001)$ or cells stimulated with thermoinactivated rickettsiae $(P<0.0001)$ (Fig. 3b). The number of dead cells (those labeled with PI) was also significantly lower among cells that were infected with viable bacteria than in the other two groups $(P<0.0002)$.

\section{Effects of caspase-3 activation on the proliferation of $R$. rickettsii in BME26 cells}

To assess the effect of the activation of caspase- 3 on the proliferation of $R$. rickettsii, the bacterial growth in BME26 cells treated with either staurosporine or Z-DEVD-Fmk, a caspase-3 inhibitor, was evaluated (Fig. 4). Rickettsia rickettsii growth was significantly higher in BME26 cells treated with Z-DEVD-Fmk than in untreated cells (control) from 72 to $120 \mathrm{~h}$ post-infection $(P<0.02)$. Specifically, the doubling time of the bacterial population in untreated cells was $7.7 \mathrm{~h}$, compared to 6.2 $\mathrm{h}$ in cells treated with Z-DEVD-Fmk. On the other hand, the induction of caspase- 3 activity with staurosporine negatively impacted bacterial growth, causing an increase in the doubling time to $11.3 \mathrm{~h}$. In this condition, a significant difference in bacterial growth compared to the 
Table 2 Selected proteins downregulated at 6 or 48 h post-R. rickettsii infection of BME26 cells

\begin{tabular}{|c|c|c|c|c|}
\hline \multirow{2}{*}{$\begin{array}{l}\text { Functional } \\
\text { class of } \\
\text { proteins }\end{array}$} & \multicolumn{2}{|l|}{$6 \mathrm{~h}$ post-infection } & \multicolumn{2}{|l|}{$48 \mathrm{~h}$ post-infection } \\
\hline & ID & Annotation & ID & Annotation \\
\hline \multirow[t]{4}{*}{$\begin{array}{l}\text { ST/ } \\
\text { APOPTOSIS }\end{array}$} & BME26USP-3827 & $\begin{array}{l}\text { Mucin-1—Negative regulation of intrinsic } \\
\text { apoptotic signaling pathway in response to } \\
\text { DNA damage by p53 class mediator }\end{array}$ & \multirow[t]{4}{*}{-} & \multirow[t]{4}{*}{-} \\
\hline & BME26USP-65523 & $\begin{array}{l}\text { Apoptosis inhibitor } 5 / \text { fibroblast growth factor } \\
\text { 2-interacting factor } 2\end{array}$ & & \\
\hline & BME26USP-74870 & Clathrin assembly protein AP180 & & \\
\hline & BME26USP-4568 & $\begin{array}{l}\text { Ubiquinone oxidoreductase b16.6 subunit/ } \\
\text { cell death }\end{array}$ & & \\
\hline \multirow[t]{6}{*}{ PROT } & BME26USP-65609 & $\begin{array}{l}\text { 20S Proteasome regulatory subunit beta type } \\
\text { PSMB4/PRE4 }\end{array}$ & \multirow[t]{6}{*}{ BME26USP-65272 } & \multirow[t]{6}{*}{ SCF ubiquitin ligase Skp1 component } \\
\hline & BME26USP-64301 & $\begin{array}{l}\text { 26S Proteasome regulatory complex ATPase } \\
\text { RPT6 }\end{array}$ & & \\
\hline & BME26USP-75557 & $\begin{array}{l}\text { 20S Proteasome regulatory subunit alpha type } \\
\text { PSMA2/PRE8 }\end{array}$ & & \\
\hline & BME26USP-4899 & $\begin{array}{l}\text { 20S Proteasome regulatory subunit beta type } \\
\text { PSMB1/PRE7 }\end{array}$ & & \\
\hline & BME26USP-77519 & $\begin{array}{l}\text { 26S Proteasome regulatory complex subunit } \\
\text { RPN10/PSMD4 }\end{array}$ & & \\
\hline & BME26USP-23319 & ATP-dependent Lon protease & & \\
\hline \multirow[t]{7}{*}{ CS } & BME26USP-75222 & Alpha tubulin & \multirow[t]{3}{*}{ BME26USP-26191 } & \multirow[t]{3}{*}{ Protein tyrosine kinase } \\
\hline & BME26USP-71918 & $\begin{array}{l}\text { Actin-related protein Arp2/3 complex subunit } \\
\text { Arp2 }\end{array}$ & & \\
\hline & BME26USP-62031 & $\begin{array}{l}\text { Cdc42 homolog/positive regulation of protein } \\
\text { kinase/maintenance of protein location/ } \\
\text { adherens junction }\end{array}$ & & \\
\hline & BME26USP-2688 & $\begin{array}{l}\text { GDP dissociation inhibitor/microtubule- } \\
\text { associated complex/protein transport/Rab } \\
\text { GDP-dissociation inhibitor }\end{array}$ & \multirow[t]{4}{*}{ BME26USP-SigP-76633 } & \multirow[t]{4}{*}{ Tyrosine kinase eph ephrin receptor family } \\
\hline & BME26USP-4897 & $\begin{array}{l}\text { Actin-related protein Arp2/3 complex subunit } \\
\text { ARPC1/p41-ARC }\end{array}$ & & \\
\hline & BME26USP-25990 & Dynein light intermediate chain & & \\
\hline & BME26USP-77773 & Microtubule-actin cross-linking factor 1 & & \\
\hline
\end{tabular}

ST/apoptosis: signal transduction and apoptosis; PROT: proteasome machinery; CS: cytoskeletal functional classes, SCF, Skp1/Cullin/F-box containing complex

control $(P<0.007)$ was detected at all time points, starting at the $6 \mathrm{~h}$ post-infection.

\section{Discussion}

Although arthropods lack the adaptive response of vertebrates, a series of effective cellular and humoral reactions are triggered after a microbial invasion to control infection [34]. Different types of cell death, including apoptosis, also play an important role in the immune defense of arthropods (as well as of other animals), as the infected cells are eliminated, thereby preventing the dissemination of the infectious agent [35-38]. To counteract the host response, the microorganisms use different strategies, including the inhibition of apoptosis, to ensure their survival and proliferation [35, 39]. For example, Ats1 , an effector of the type IV secretion system (T4SS) of the tick-borne bacterium Anaplasma phagocytophilum (causative agent of human granulocytic anaplasmosis), inhibits the mitochondrial release of the pro-apoptotic cytochrome $c$, delaying host cell apoptosis [40]. The delay of apoptosis is crucial for the completion of the bacterial life-cycle within neutrophils [41, 42]. Anaplasma phagocytophilum is also capable of manipulating the apoptosis of its tick vector [43-47].

In the present study, we showed that the infection with $R$. rickettsii alters the proteome of BME26 cells in a time-dependent manner. Regarding proteins involved in apoptosis, certain negative regulators were downregulated at $6 \mathrm{~h}$ post-infection with $R$. rickettsii but upregulated at $48 \mathrm{~h}$ post-infection. As mentioned earlier in this article, previous studies have shown that $R$. rickettsii is capable of inhibiting apoptosis in human endothelial cells [14-16]. In this process, the activation of the nuclear transcription factor-kappa B (NF-kB) by infection is crucial [14]. NF-kB controls the levels 


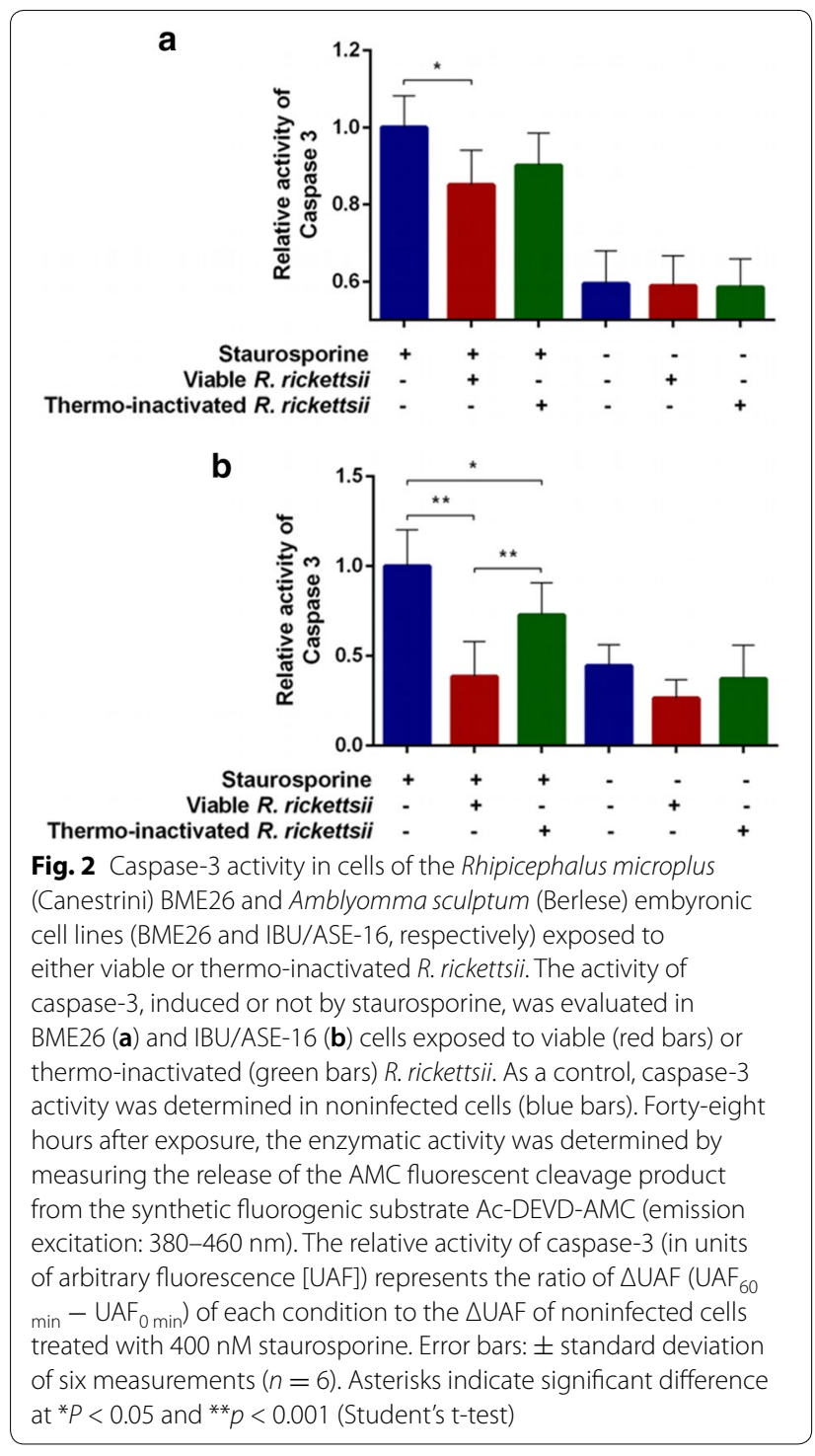

and/or the localization of proteins from the B-cell lymphoma 2 (Bcl-2) family [15], which, in turn, prevents the activation of the apical caspases -8 and -9 , as well as the effector caspase-3 [16]. We therefore hypothesized that $R$. rickettsii could also subvert apoptosis in tick cells, as suggested by proteome data. The fragmentation of DNA, a classic marker of apoptotic cells [48], was detected only in noninfected BME26 cells. Moreover, the activity of the executioner caspase- 3 was assessed in two distinct tick cell lines, the BME26 from R. microplus and the IBU/ASE-16 from A. sculptum. The activity of caspase- 3 was significantly lower in both $R$. rickettsii-infected cell lines in comparison to noninfected cells. Caspase-3 was also significantly lower in IBU/ASE-16 cells exposed to thermo-inactivated rickettsiae than in the control cells, suggesting that components produced by live $R$. rickettsii may inhibit caspase- 3 activity. Inhibition of caspase- 3 activity by thermo-inactivated bacteria compared to the control might be due to the leakage components of dead bacteria, as BME26 cells exhibit a phagocytic activity [8].

The translocation of phosphatidylserine from the inner to the outer layer of the plasma membrane is another important feature of apoptotic cells, allowing their recognition and elimination by phagocytic cells [49]. A higher number of noninfected BME26 cells were labeled with annexin- $\mathrm{V}$ when compared to the cells infected with viable $R$. rickettsii, showing that infection reduces the exposure of phosphatidylserine. Calreticulin is considered to be the second recognition ligand of the apoptotic cell, binding to the low-density lipoprotein (LDL)-receptorrelated protein of the phagocytic cell [50]. Interestingly, proteome data showed that one LDL-receptor-related protein was upregulated at $6 \mathrm{~h}$ (Additional file 3: Table S1) and downregulated at $48 \mathrm{~h}$ (Additional file 6: Table S4) post-infection of BME26 cells.

The proteome of BME26 cells also revealed that components of the ubiquitin-proteasome system were modulated at both time points after infection of BME26 cells. This system plays a key role in the degradation of damaged endogenous proteins or those with errors of synthesis, as well as in the regulation of several cellular processes [51, 52], including apoptosis [53]. The target proteins are marked for degradation by ubiquitination, which is catalyzed by three enzymes: ubiquitinactivating enzyme (E1), ubiquitin-conjugating enzyme (E2) and ubiquitin-protein ligase (E3) [54, 55]. Interestingly, it was previously reported that the chemical inhibition of the proteasome system of human endothelial cells by MG-132 leads to rapid death upon infection with $R$. rickettsii, as it prevents the degradation of the NF-kB inhibitor and, consequently, the apoptotic process is not inhibited [14]. In our study, at $6 \mathrm{~h}$ post-infection with $R$. rickettsii, the ubiquitin $\mathrm{C}$-terminal hydrolase, an enzyme that cleaves ubiquitin from proteins and other molecules [54], was downregulated. Moreover, a proteasome inhibitor was upregulated, suggesting that the ubiquitin-proteasome system is inhibited at the beginning of the infection. The modulation of the proteasome inhibitor was not detected at $48 \mathrm{~h}$ post-infection. At $48 \mathrm{~h}$, one ubiquitin ligase (E3) was also upregulated. In Ixodes scapularis, the knockdown of the X-linked inhibitor of apoptosis protein (XIAP), which possesses a really interesting new gene (RING) zinc-finger motif that exhibits E3-ubiquitin ligase activity, increased the colonization by Anaplasma phagocytophilum, showing that E3 is important for the control of infection [56]. Indeed, it has been described that ubiquitination regulates arthropod immune responses against microorganisms [55]. 


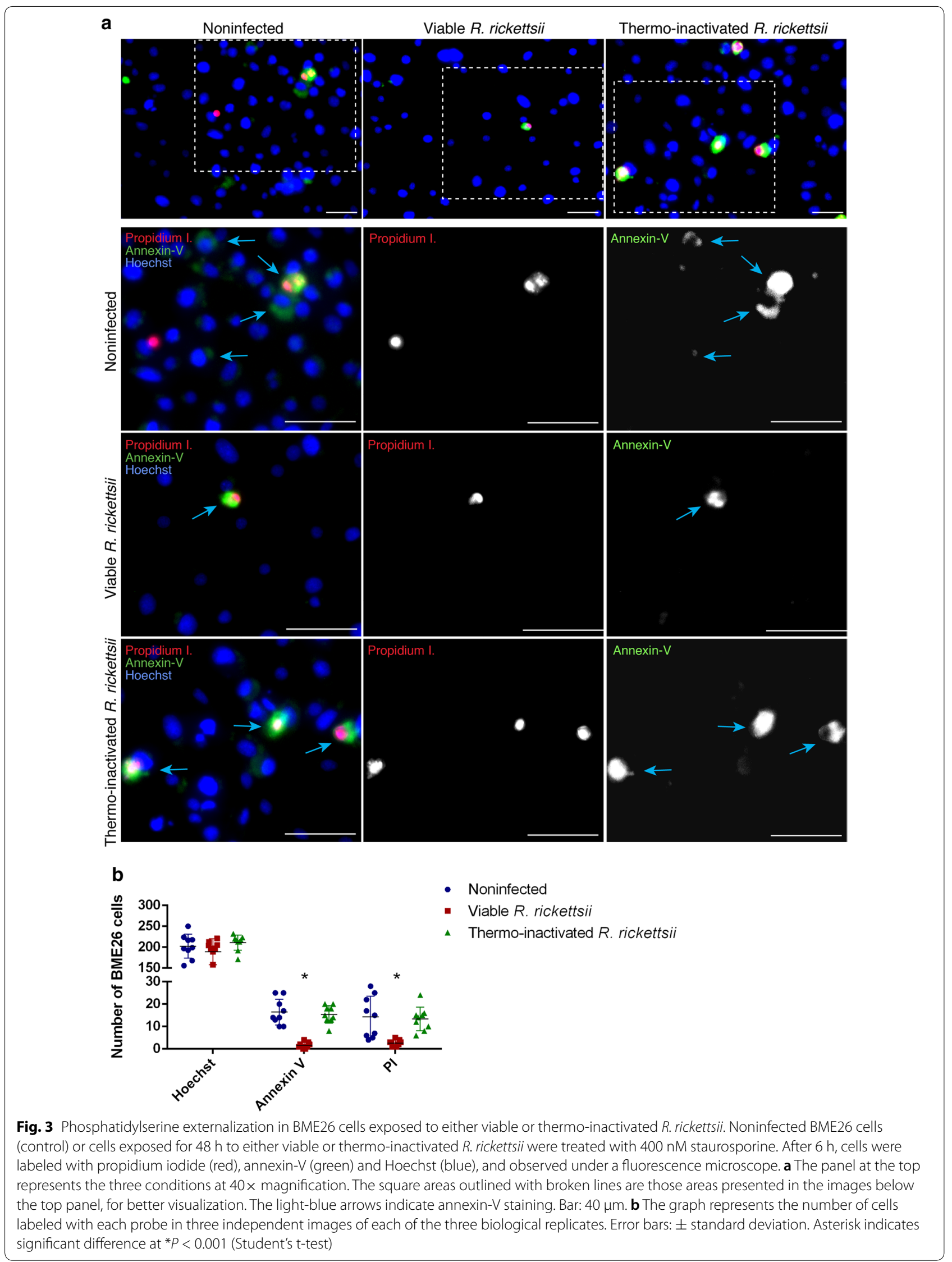




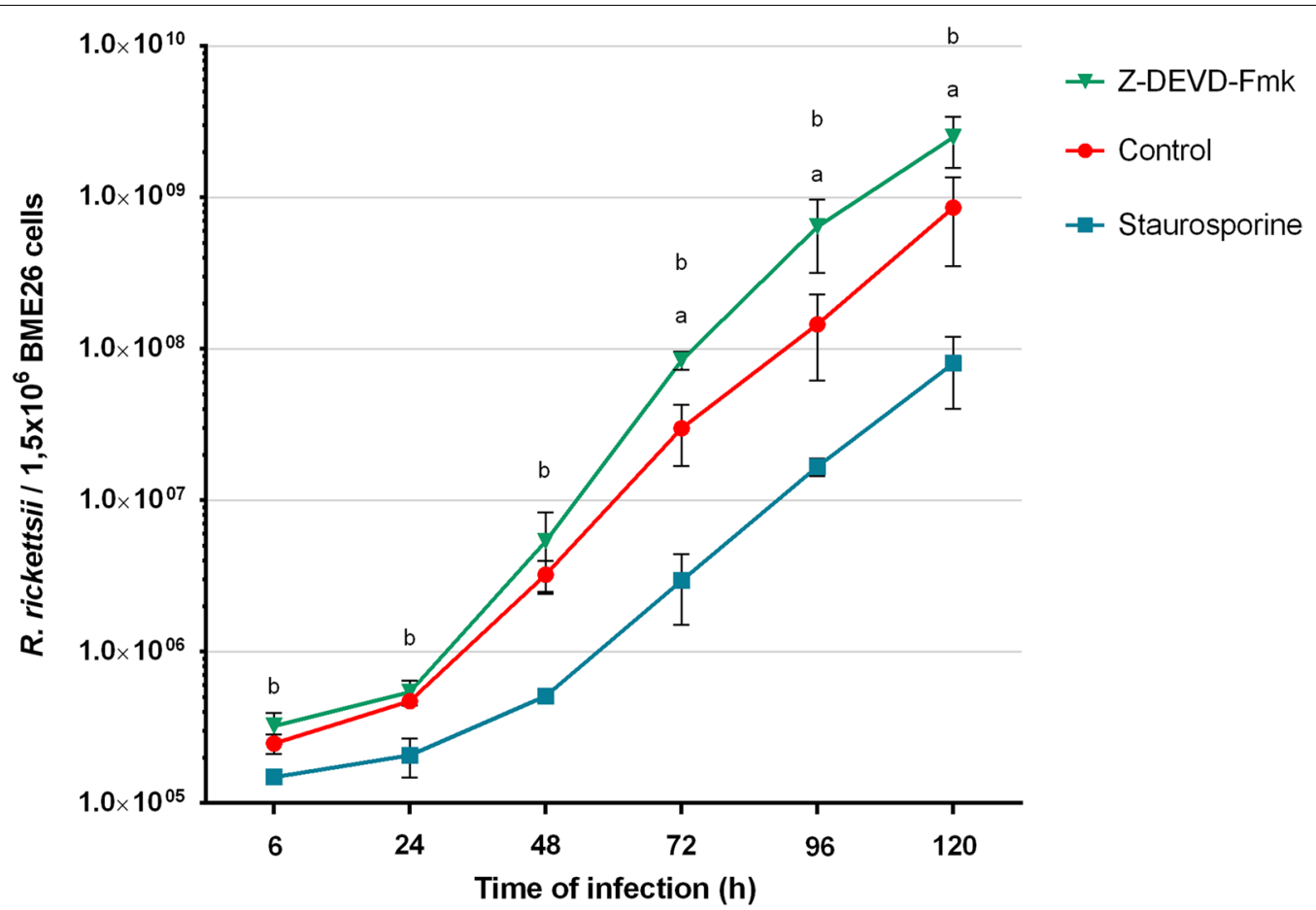

Fig. 4 Growth curve of R. rickettsii in BME26 cells treated with either staurosporine or the caspase-3 inhibitor Z-DEVD-Fmk. BME26 cells were treated with staurosporine $(400 \mathrm{nM})$ or the caspase-3 inhibitor Z-DEVD-Fmk $(10 \mu \mathrm{M})$. Untreated cells served as the control. After $1 \mathrm{~h}$, cells were inoculated with $R$. rickettsii. The number of rickettsiae after $6,24,48,72,96$ and $120 \mathrm{~h}$ was determined by quantitative PCR using specific primers and a hydrolysis probe for the single-copy gene gltA of Rickettsia spp. ${ }^{\text {a }}$ Significant difference in rickettsial growth in cells treated with Z-DEVD-Fmk $(P<$ 0.02 , Student's t-test), ${ }^{\mathrm{b}}$ significant difference in rickettsial growth in cells treated with staurosporine $(P<0.007$, Student's t-test), compared to the control. Error bars: \pm standard deviation $(n=3)$

In our study, proteins of the cytoskeletal category were also modulated by infection of BME26 cells with $R$. rickettsii. Among these, we highlight subunits of the Arp2/3 complex and spectrin. Members of the genus Rickettsia, which compose the spotted fever group, polymerize the host actin to move within the host cell as well as to invade adjacent cells [57-60]. This process is mediated by the bacterial RickA protein, which activates the Arp2/3 complex of the host cell in one of the poles of the bacterium, triggering actin polymerization and the propulsion of the bacterium. Therefore, the modulation of proteins of the Arp2/3 complex during infection is important to assure the spread of rickettsiae. More recently, actinrelated proteins have also been associated with apoptosis $[61,62]$. Indeed, it was previously reported that spectrin is involved in rearrangement of the cell cytoskeletal in the case of infection [63], which can also activate apoptosis [64]. Interestingly, the knockdown of spectrin caused a diminution of $A$. phagocytophilum load in the midgut, salivary glands and the embryonic cell line ISE6 of I. scapularis [43].

Importantly, the growth of $R$. rickettsii was higher in BME26 cells treated with the caspase-3 inhibitor and lower in those treated with staurosporine, indicating that the activation of apoptosis is detrimental while its inhibition favors rickettsial proliferation. Moreover, it is also possible that $R$. rickettsii cannot efficiently invade apoptotic cells, which further reinforces the importance of regulating this process to guarantee cellular invasion.

\section{Conclusions}

Taken together, our data showed that $R$. rickettsii modulate the proteome of BME26 cells, including proteins enrolled with apoptosis, and exerts an inhibitory effect on the apoptosis in tick cells, which seems to be advantageous to ensure its proliferation in tick cells. 


\section{Supplementary information}

Supplementary information accompanies this paper at https://doi. org/10.1186/s13071-020-04477-5.

Additional file 1: FASTA file. Deduced amino acid sequences from transcripts of BME26 cells and protein sequences from bacteria of the genus Rickettsia.

Additional file 2: Figure S1. Growth curve and photomicrograph of $R$ rickettsii in BME26 cells. The number of rickettsiae was determined at each time point by GPCR using specific primers and a hydrolysis probe for the single-copy gene gltA (A). Error bars: $\pm \mathrm{SD}(n=3)$. Aliquots of BME26 were removed at $24 \mathrm{~h}(\mathbf{B}), 48 \mathrm{~h}(\mathbf{C}), 72 \mathrm{~h}(\mathbf{D})$ and $96 \mathrm{~h}(\mathbf{E})$ post-infection, stained by Gimenez and visualized under a light microscope. A high concentration of rickettsiae (colored in purple and indicated by the arrows) was observed in the nuclei $(n)$ of the cells at 24 (b) and $48 \mathrm{~h}$ (c).

Additional file 3: Table S1. Proteins differentially expressed in BME26 cells after $6 \mathrm{~h}$ of infection with $R$. rickettsii.

Additional file 4: Table S2. Proteins exclusively identified in noninfected BME26 cells (control) at $6 \mathrm{~h}$

Additional file 5: Table S3. Proteins exclusively identified in $R$. rickettsiiinfected BME26 cells at $6 \mathrm{~h}$

Additional file 6: Table S4. Proteins differentially expressed in BME26 cells after 48 h of infection with $R$. rickettsii.

Additional file 7: Table S5. Proteins exclusively identified in noninfected BME26 cells (control) at $48 \mathrm{~h}$.

Additional file 8: Table S6. Proteins exclusively identified in R. rickettsiiinfected BME26 cells at $48 \mathrm{~h}$.

Additional file 9: Table S7. Rickettsia spp. proteins identified in BME26 cells by LC-MS/MS

Additional file 10: Figure S2. Global sample characterization and comparison of proteins identified in noninfected and $R$. rickettsii-infected BME26 cells by LC-MS/MS. Venn diagrams displaying the total number of tick proteins that were exclusively detected in one condition or shared among different conditions: A noninfected (control) and $R$. rickettsiiinfected cells at 6 or $48 \mathrm{~h}$ post-infection. B Principal component analysis (PCA) plot of protein datasets ( $C$ control biological replicates, / infected biological replicates, 6 or $48 \mathrm{~h}$ post-infection; PC1 principal component 1, $P C 2$ principal component 2). C $\mathbf{D}$ Venn diagrams showing proteins that were exclusively detected or were detected in both noninfected and $R$. rickettsii infected cells at $6 \mathrm{~h}(\mathbf{C})$ and $48 \mathrm{~h}(\mathbf{D})$ post-infection. Among shared proteins, only those with $P<0.05$ and a fold-change $\geq 1.5$ or $\leq 0.67$ were considered modulated by infection.

Additional file 11: Figure S3. Analysis of the gDNA extracted from noninfected and $R$. rickettsii-infected BME26 cells by agarose gel electrophoresis. The gDNA extracted from noninfected (control) or $R$. rickettsii-infected BME26 cells at 6, 24, 48, 72, 96 and $120 \mathrm{~h}$ post-infection was separated on a $1 \%$ agarose gel electrophoresis stained with RED $^{\text {TM }}$ Gel and visualized under UV light. DNA marker size (bp) is shown.

Additional file 12: Figure S4. Caspase-3 activity in BME26 at different times after infection with $R$. rickettsii. BME26 cells previously infected with $R$. rickettsii for 24,36 , and $48 \mathrm{~h}$ (red bars) were treated with $400 \mathrm{nM}$ staurosporine. As a control, noninfected cells (blue bars) were also treated with $400 \mathrm{nM}$ of staurosporine. The enzymatic reaction was carried out at $37^{\circ} \mathrm{C}$ for $60 \mathrm{~min}$, and hydrolysis was measured by the release of the fluorescent cleavage product AMC from the synthetic fluorogenic substrate Ac-DEVDAMC (emission-excitation: $380-460 \mathrm{~nm}$ ). The relative activity of caspase-3 (in units of arbitrary fluorescence [UAF]) represents the ratio of $\triangle U A F$ $\left(U A F_{60 \text { min }}-U A F_{0 \text { min }}\right)$ of each condition to the $\triangle U A F$ of noninfected cells in each time analyzed. Error bars: $\pm \operatorname{SD}(n=3)$. ${ }^{*}$ Significantly different at $P$ $<0.05$ (Student's t-test).

\section{Acknowledgements}

We would like to thank Drs. Fernando G. de Almeida and Claudia B. Angeli for assistance at CEFAP/USP proteomic facility.

\section{Authors' contributions}

LAM, ACF, GP, MC, SD designed the experiments. LAM, DBB, EE generated biological samples. LAM, MC, BIA performed the experiments. LAM, RK, GP analyzed proteome data. LAM, RK, AF performed statistic data analysis. ACF, $\mathrm{SD}, \mathrm{AF}, \mathrm{GB}$, JMFB, MC, LT contributed reagents/materials/analysis tools. LAM, ACF wrote the paper. All authors read and approved the final version of the manuscript.

\section{Funding}

This work was supported by funds from: the São Paulo Research Foundation (FAPESP), mainly by Grants 2013/26450-2 and 2014/11513-1, and with a minor contribution of Grants 2007/57749-2, 2012/24105-3, 2014/06863-3, 2018/18257-1, and 2018/15549-1; the National Council for Scientific and Technological Development [CNPq; Grants CNPq 573959/2008-0; the National Institutes of Science and Technology Program in Molecular Entomology (INCTEM)]; the Coordination for the Improvement of Higher Education Personnel (CAPES); and the Provost for Research of the University of São Paulo [Research Support Center on Bioactive Molecules from Arthropod Vectors (NAPMOBIARVE 12.1.17661.1.7)]. LAM was supported by fellowships from CNPq (142029/2014-9), FAPESP (2014/05855-7) and CAPES. ACF (309733/2018-9) and SD (304382/2017-5) received CNPq research productivity scholarships.

\section{Availability of data and materials}

The mass spectrometry raw files were submitted to PRIDE (https://www.ebi. ac.uk/pride/) with the submission number PXD017942. The BME26 RNA-seq raw data were deposited to the Sequence Read Archives (SRA) of the NCBI under bioproject number PRJNA607772 and the Transcriptome Shotgun Assembly (TSA) project has been deposited at DDBJ/EMBL/GenBank under the accession GINU00000000 (the version described here is the first version, GINU01000000). The authors declare that all other data supporting the findings of this study are available within the article and its Additional Information files.

\section{Ethics approval and consent to participate}

Not applicable.

\section{Consent for publication}

Not applicable.

\section{Competing interests}

The authors declare that they have no competing interests.

\section{Author details}

${ }^{1}$ Department of Parasitology, Institute of Biomedical Sciences, University of São Paulo, São Paulo, SP, Brazil. ${ }^{2}$ Department of Computational Science, Institute of Mathematics and Statistics, University of São Paulo, São Paulo, SP, Brazil. ${ }^{3}$ Department of Veterinary Pathology, São Paulo State University, Jaboticabal, SP, Brazil. ${ }^{4}$ Department of Biochemistry, Institute of Chemistry, Federal University of Rio de Janeiro, Rio de Janeiro, RJ, Brazil. ${ }^{5}$ Rocky Mountain Laboratories, National Institutes of Health, National Institute of Allergy and Infectious Diseases, Hamilton, MT, USA. ${ }^{6}$ Present Address: Rocky Mountain Laboratories, National Institutes of Health, National Institute of Allergy and Infectious Diseases, Hamilton, USA. ${ }^{7}$ Present Address: Department of Molecular Sciences, Macquarie University, Sydney, NSW, Australia.

Received: 17 August 2020 Accepted: 5 November 2020

Published online: 01 December 2020

\section{References}

1. Dantas-Torres F, Chomel BB, Otranto D. Ticks and tick-borne diseases: a one health perspective. Trends Parasitol. 2012;28:437-46.

2. Walker DH, Paddock CD, Dumler JS. Emerging and re-emerging ticktransmitted rickettsial and ehrlichial infections. Med Clin North Am. 2008;92:1345-61. 
3. Wikel SK. Ticks and tick-borne Infections: complex ecology, agents, and host interactions. Vet Sci. 2018;5:60.

4. Labruna MB. Ecology of rickettsia in South America. Ann N Y Acad Sci. 2009;1166:156-66.

5. Chen LF, Sexton DJ. What's new in Rocky Mountain spotted fever? Infect Dis Clin North Am. 2008;22:415-32.

6. Dantas-Torres F. Rocky Mountain spotted fever. Lancet Infect Dis. 2007;7:724-32.

7. Bell-Sakyi L, Darby A, Baylis M, Makepeace BL. The tick cell biobank: a global resource for in vitro research on ticks, other arthropods and the pathogens they transmit. Ticks Tick Borne Dis. 2018;9:1364-71.

8. Esteves E, Lara FA, Lorenzini DM, Costa GHN, Fukuzawa AH, Pressinotti LN, et al. Cellular and molecular characterization of an embryonic cell line (BME26) from the tick Rhipicephalus (Boophilus) microplus. Insect Biochem Mol Biol. 2008;38:568-80.

9. Kurtti TJ, Munderloh UG, Krueger DE, Johnson RC, Schwan TG. Adhesion to and invasion of cultured tick (Acarina: Ixodidae) cells by Borrelia burgdorferi (Spirochaetales: Spirochaetaceae) and maintenance of infectivity. J Med Entomol. 1993;30:586-96.

10. Esteves E, Bastos CV, Zivkovic Z, de La Fuente J, Kocan K, Blouin E, et al. Propagation of a Brazilian isolate of Anaplasma marginale with appendage in a tick cell line (BME26) derived from Rhipicephalus (Boophilus) microplus. Vet Parasitol. 2009;161:150-3.

11. Bifano TD, Ueti MW, Esteves E, Reif KE, Braz GRC, Scoles GA, et al. Knockdown of the Rhipicephalus microplus cytochrome c oxidase subunit III gene is associated with a failure of Anaplasma marginale transmission. PLOS ONE. 2014:9:1-10.

12. Rosa RD, Capelli-Peixoto J, Mesquita RD, Kalil SP, Pohl PC, Braz GR, et al. Exploring the immune signalling pathway-related genes of the cattle tick Rhipicephalus microplus: from molecular characterization to transcriptional profile upon microbial challenge. Dev Comp Immunol. 2016:59:1-14.

13. Kalil SP, da Rosa RD, Capelli-Peixoto J, Pohl PC, de Oliveira PL, Fogaça AC, et al. Immune-related redox metabolism of embryonic cells of the tick Rhipicephalus microplus (BME26) in response to infection with Anaplasma marginale. Parasites Vectors. 2017;10:613.

14. Clifton DR, Goss RA, Sahni SK, van Antwerp D, Baggs RB, Marder VJ, et al. NF-kB-dependent inhibition of apoptosis is essential for host cell survival during Rickettsia rickettsii infection. Proc Natl Acad Sci USA. 1998:95:4646-51.

15. Joshi SG, Francis CW, Silverman DJ, Sahni SK. NF-kappaB activation suppresses host cell apoptosis during Rickettsia rickettsii infection via regulatory effects on intracellular localization or levels of apoptogenic and anti-apoptotic proteins. FEMS Microbiol Lett. 2004;234:333-41.

16. Joshi SG, Francis CW, Silverman DJ, Sahni SK. Nuclear factor kB protects against host cell apoptosis during Rickettsia rickettsii infection by inhibiting activation of apical and effector caspases and maintaining mitochondrial integrity. Infect Immun. 2003;71:4127-36.

17. Munderloh UG, Kurtti TJ. Formulation of medium for tick cell culture. Exp Appl Acarol. 1989;7:219-29.

18. Moraes AC. Establishment and characterization of embryonic cells of Amblyomma sculptum Berlese (Acari: Ixodidae). In: Biblioteca Digital de Teses e Dissertações da Universidade de São Paulo. 2016. https:// www.teses.usp.br/teses/disponiveis/87/87131/tde-04122015-152642/: Accessed 15 Jun 2020

19. Peredeltchouk M, Wilson David SA, Bhattacharya B, Volokhov DV, Chizhikov V. Detection of mycoplasma contamination in cell substrates using reverse transcription-PCR assays. J Appl Microbiol. 2011;1 10:54-60.

20. Pinter A, Labruna MB. Isolation of Rickettsia rickettsii and Rickettsia bellii in cell culture from the tick Amblyomma aureolatum in Brazil. Ann N Y Acad Sci. 2006;1078:523-9.

21. Esteves E, Bizzarro B, Costa FB, Ramírez-Hernández A, Peti APF, Cataneo $A H D$, et al. Amblyomma sculptum salivary PGE2 modulates the dendritic cell-Rickettsia rickettsii interactions in vitro and in vivo. Front Immunol. 2019;10:118.

22. Bustin SA, Benes V, Garson JA, Hellemans J, Huggett J, Kubista M, et al. The MIQE guidelines: minimum information for publication of quantitative real-time PCR experiments. Clin Chem. 2009;55:611-22.

23. Galletti MFBM, Fujita A, Nishiyama MY Jr, Malossi CD, Pinter A, Soares JF, et al. Natural blood feeding and temperature shift modulate the global transcriptional profile of Rickettsia rickettsii infecting its tick vector. PLoS ONE. 2013;8:e77388.

24. Ammerman NC, Beier-Sexton M, Azad AF. Laboratory maintenance of Rickettsia rickettsii. In: Current protocols in microbiology. Hoboken: Wiley; 2008. p. 1-26.

25. Nakayasu ES, Sobreira TJP, Torres R, Ganiko L, Oliveira PSL, Marques $A F$, et al. Improved proteomic approach for the discovery of potential vaccine targets in Trypanosoma cruzi. J Proteome Res. 2012:11:237-46.

26. Cox J, Mann M. MaxQuant enables high peptide identification rates, individualized p.p.b.-range mass accuracies and proteome-wide protein quantification. Nat Biotechnol. 2008;26:1367-72.

27. Cox J, Neuhauser N, Michalski A, Scheltema RA, Olsen JV, Mann M. Andromeda: a peptide search engine integrated into the MaxQuant environment. J Proteome Res. 2011;10:1794-805.

28. UniProt Consortium. UniProt: a hub for protein information. Nucleic Acids Res. 2015;43:D204-12.

29. Xia J, Sinelnikov IV, Han B, Wishart DS. MetaboAnalyst 3.0-making metabolomics more meaningful. Nucleic Acids Res. 2015;43:W251-7.

30. Schneider CA, Rasband WS, Eliceiri KW. NIH Image to ImageJ: 25 years of image analysis. Nat Methods. 2012;9:671-5.

31. Karim S, Browning R, Ali L, Truhett R. Laboratory-infected Ehrlichia chaffeensis female adult Amblyomma americanum salivary glands reveal differential gene expression. J Med Entomol. 2012:49:547-54.

32. Bertrand R, Solary E, O'Connor P, Kohn KW, Pommier Y. Induction of a common pathway of apoptosis by staurosporine. Exp Cell Res. 1994:211:314-21.

33. van Engeland M, Nieland LJW, Ramaekers FCS, Schutte B, Reutelingsperger CPM. Annexin V-affinity assay: a review on an apoptosis detection system based on phosphatidylserine exposure. Cytometry. 1998;31:1-9.

34. Baxter RHG, Contet A, Krueger K. Arthropod innate immune systems and vector-borne diseases. Biochemistry. 2017;56:907-18.

35. Ashida H, Mimuro H, Ogawa M, Kobayashi T, Sanada T, Kim M, et al. Cell death and infection: a double-edged sword for host and pathogen survival. J Cell Biol. 2011:195:931-42.

36. Steinert S, Levashina EA. Intracellular immune responses of dipteran insects. Immunol Rev. 2011;240:129-40.

37. Cooper D, Mitchell-Foster K. Death for survival: what do we know about innate immunity and cell death in insects? Invertebrate Surviv J. 2011:8:162-72

38. Lamkanfi M, Dixit VM. Manipulation of host cell death pathways during microbial infections. Cell Host Microbe. 2010:8:44-54.

39. Rudel T, Kepp O, Kozjak-Pavlovic V. Interactions between bacterial pathogens and mitochondrial cell death pathways. Nat Rev Microbiol. 2010;8:693-705.

40. Niu H, Kozjak-Pavlovic V, Rudel T, Rikihisa Y. Anaplasma phagocytophilum Ats-1 is imported into host cell mitochondria and interferes with apoptosis induction. PLoS Pathog. 2010;6:e1000774.

41. Ge Y, Rikihisa Y. Anaplasma phagocytophilum delays spontaneous human neutrophil apoptosis by modulation of multiple apoptotic pathways. Cell Microbiol. 2006:8:1406-16.

42. Ge Y, Yoshiie K, Kuribayashi F, Lin M, Rikihisa Y. Anaplasma phagocytophilum inhibits human neutrophil apoptosis via upregulation of bfl-1, maintenance of mitochondrial membrane potential and prevention of caspase 3 activation. Cell Microbiol. 2004;7:29-38.

43. Ayllón N, Villar M, Busby AT, Kocan KM, Blouin EF, Bonzón-Kulichenko E, et al. Anaplasma phagocytophilum inhibits apoptosis and promotes cytoskeleton rearrangement for infection of tick cells. Infect Immun. 2013;81:2415-25.

44. Ayllón N, Villar M, Galindo RC, Kocan KM, Šíma R, López JA, et al. Systems biology of tissue-specific response to Anaplasma phagocytophilum reveals differentiated apoptosis in the tick vector Ixodes scapularis. PLoS Genet. 2015;11:1-29.

45. Cabezas-Cruz A, Alberdi P, Ayllón N, Valdés JJ, Pierce R, Villar M, et al. Anaplasma phagocytophilum increases the levels of histone modifying enzymes to inhibit cell apoptosis and facilitate pathogen infection in the tick vector Ixodes scapularis. Epigenetics. 2016;11:303-19.

46. Villar M, Ayllón N, Alberdi P, Moreno A, Moreno M, Tobes R, et al. Integrated metabolomics, transcriptomics and proteomics identifies metabolic pathways affected by Anaplasma phagocytophilum infection in tick cells. Mol Cell Proteomics. 2015:14:3154-72. 
47. Alberdi P, Ayllón N, Cabezas-Cruz A, Bell-Sakyi L, Zweygarth E, Stuen S, et al. Infection of Ixodes spp. tick cells with different Anaplasma phagocytophilum isolates induces the inhibition of apoptotic cell death. Ticks Tick Borne Dis. 2015;6:758-67.

48. Bortner CD, Oldenburg NBE, Cidlowski JA. The role of DNA fragmentation in apoptosis. Trends Cell Biol. 1995;5:21-6.

49. Bratton DL, Fadok VA, Richter DA, Kailey JM, Guthrie LA, Henson PM. Appearance of phosphatidylserine on apoptotic cells requires calciummediated nonspecific flip-flop and is enhanced by loss of the aminophospholipid translocase. J Biol Chem. 1997;272:26159-65.

50. Gardai SJ, MCPhillips KA, Frasch SC, Janssen WJ, Starefeldt A, MurphyUllrich JE, et al. Cell-surface calreticulin initiates clearance of viable or apoptotic cells through trans-activation of LRP on the phagocyte. Cell. 2005; 123:321-34.

51. Lecker SH. Protein degradation by the ubiquitin-proteasome pathway in normal and disease states. J Am Soc Nephrol. 2006;17:1807-19.

52. Kudriaeva AA, Belogurov AA. Proteasome: a nanomachinery of creative destruction. Biochemistry. 2019;84:159-92.

53. Bader M, Steller H. Regulation of cell death by the ubiquitin-proteasome system. Curr Opin Cell Biol. 2009;21:878-84.

54. Reyes-Turcu FE, Ventii KH, Wilkinson KD. Regulation and cellular roles of ubiquitin-specific deubiquitinating enzymes. Annu Rev Biochem. 2009;78:363-97.

55. Severo MS, Sakhon OS, Choy A, Stephens KD, Pedra JHF. The 'ubiquitous' reality of vector immunology. Cell Microbiol. 2013;15:1070-8.

56. Severo MS, Choy A, Stephens KD, Sakhon OS, Chen G, Chung DWD, et al. The E3 ubiquitin ligase XIAP restricts Anaplasma phagocytophilum colonization of Ixodes scapularis ticks. J Infect Dis. 2013;208:1830-40.
57. Gouin E, Egile C, Dehoux P, Villiers V, Adams J, Gertler F, et al. The RickA protein of Rickettsia conorii activates the Arp2/3 complex. Nature. 2004;427:457-61.

58. Gouin E, Welch MD, Cossart P. Actin-based motility of intracellular pathogens. Curr Opin Microbiol. 2005;8:35-45.

59. Dramsi S, Cossart P. Intracellular pathogens and the actin cytoskeleton. Annu Rev Cell Dev Biol. 1998;14:137-66.

60. Jeng RL, Goley ED, D'Alessio JA, Chaga OY, Svitkina TM, Borisy GG, et al. A Rickettsia WASP-like protein activates the Arp2/3 complex and mediates actin-based motility. Cell Microbiol. 2004;6:761-9.

61. Desouza M, Gunning PW, Stehn JR. The actin cytoskeleton as a sensor and mediator of apoptosis. Bioarchitecture. 2012;2:75-87.

62. Franklin-Tong VE, Gourlay CW. A role for actin in regulating apoptosis/ programmed cell death: evidence spanning yeast, plants and animals. Biochem J. 2008;413:389-404.

63. Broderick MJF, Winder SJ. Spectrin, alpha-actinin, and dystrophin. Adv Protein Chem. 2005;70:203-46.

64. Machnicka B, Czogalla A, Hryniewicz-Jankowska A, Bogusławska DM, Grochowalska R, Heger E, et al. Spectrins: a structural platform for stabilization and activation of membrane channels, receptors and transporters. Biochim Biophys Acta Biomembr. 2014;1838:620-34.

\section{Publisher's Note}

Springer Nature remains neutral with regard to jurisdictional claims in published maps and institutional affiliations.
Ready to submit your research? Choose BMC and benefit from:

- fast, convenient online submission

- thorough peer review by experienced researchers in your field

- rapid publication on acceptance

- support for research data, including large and complex data types

- gold Open Access which fosters wider collaboration and increased citations

- maximum visibility for your research: over $100 \mathrm{M}$ website views per year

At BMC, research is always in progress.

Learn more biomedcentral.com/submissions 